\title{
Dedicated to Descartes' Niece: The Women's Movement in the Nineteenth Century and Anti-Vivisection
}

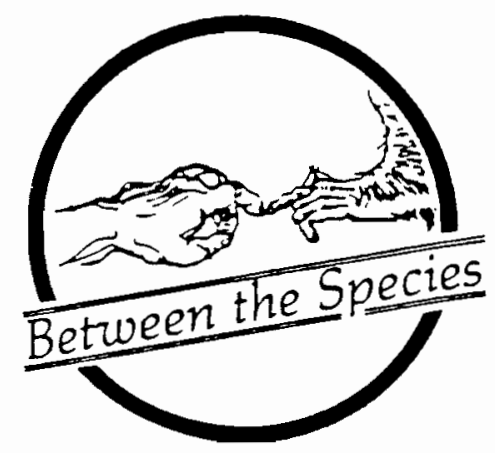

\section{Roberta Kalechofsky}

\author{
Jews for Animal Rights
}

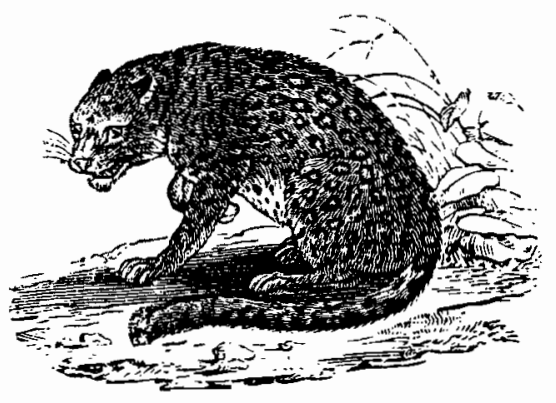

From the moment that Descartes' concept of the animal machine-legitimating vivisection-appeared in philosophical circles, there was opposition to the concept voiced by famous women of the era. Madame de Scudery, a friend of Leibniz, ran an "anti-Cartesian salon" and wrote a novel praising animal virtue. The worldly Madame de Sevigny wrote her daughter: "machines which love, which show preference for someone, machines which are jealous, machines which are afraid, come, come, be serious, never did Descartes intend to make us believe that." ${ }^{11}$ Madame de Scudery wittily argues that her pets, a monkey, a parrot, and a dog, demonstrated intelligence by their affection for her, and she determinedly spoke Latin to her parrot. More seriously, she wrote: "The tiniest monkey, by its industry and intelligence, destroys all of Descartes' doctrines." Curiously, it was this "perfection" in animals which contributed a deadly plank to Descartes' thesis, for he argues that it was animals' showing such perfection that raised the suspicion of their being machines.

Among the famous, many rejected Descartes' thesis of the "animal-machine:" Montaigne, La Fontaine, Fontenelle, Cyrano de Bergerac. Among the women, none was more famous for her opposition than

Descartes' niece, Catherine. A poet of note in her time, her position caused "a little domestic disagreement within the family of the great Descartes, when his brother's daughter espoused the doctrine of a rival philosopher (Gassendi) rather than accept the hypothesis of the beast-machine." Leonora Cohen Rosenfield has written that "her rebellion against animal automatism stands out in startling relief against the general pattern of fervent adoration for her celebrated uncle."

Gassendi argued for the principle of the "two-fold soul:" that possessed by human beings which was immortal, and that possessed by animal life, which was not immortal. It was a compromise position between a theological difficulty about salvation and a position which would expunge vitalism from the universe and could, as Bossuet predicted it would, make common cause with atheism. These opposing views in the interpretation of animal virtue foreshadowed the difference two centuries later between Claude Bernard, the "father" of animal research, and Elizabeth Blackwell, the first woman to receive a medical degree. Both beheld the intricate interior of animal life with amazement. But where Bernard saw the possibilities of mechanistic science in the body of the animal, Elizabeth Blackwell saw evidence of a living God.

Many who were engaged in the crusade against vivisection, notably Frances Power Cobbe and Anna Kingsford in this regard, understand the struggle in

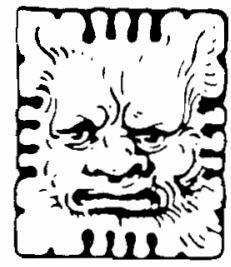

HISTORY OF IDEAS 
religious terms. Westacott, in his comprehensive survey, A Century of Vivisection and Anti-Vivisection, states that the movement inherited a religious base from Cobbe. ${ }^{3}$ After a spiritual crisis, in which she threw off her family's Orthodox Christianity and embraced Theism, Cobbe pointed out in her autobiography that "recognition of the claims of animals had been one of the first results of religious perception." Anna Kingsford wrote: "If it be necessary in order to know ... that deeds abhorrent to moral feeling should be performed, then obviously Justice is not the essential principle of the universe, and religion has no substantial basis."4

Proponents of animal research today never address the religious aspect of the problem, preferring to organize their arguments around such terms as "antiintellectual," "obscurantist," "irrational," and "antihuman." These words were used to describe women in the nineteenth century, most particularly intellectual women who were regarded as desexed. Anna Kingsford's professor at La Charité refused to record her name in his roll book, saying: "You are neither male nor female; I do not wish to write your name." Men who opposed vivisection, and this included many doctors in the nineteenth century and virtually every writer and artist, were regarded as "effeminate," which in turn meant "anti-intellectual," "irrational," and "sentimental." The gender aspect of the issue became prominent, while the moral and religious aspects were derided by the advocates of vivisection. Elie de Cyon, a prominent physiologist of the time, snickeringly asked:

Is it necessary to repeat that women-or rather, old maids, form the most numerous contingent of this group? Let my adversaries contradict me, if they can show among the leaders of the agitation one girl, rich, beautiful, and loved, or some young wife who has found in her home the full satisfactions of her affections.

Reality was irrelevant to the accusation, for the women who founded and led the anti-vivisection movement were by and large privileged, loved, dynamic, brilliant, often socially successful (like Frances Power Cobbe) and sometimes uncommonly beautiful, like Louise Augusta Lind-af-Hageby, from Sweden, and the majestic Anna Kingsford who, with her mass of wavy golden hair, resembled the ideal of the pre-Raphaelite poets. But their beauty only inspired further male derision and barbed heckling from medical students when they appeared on a platform. The propaganda stuck because it was nourished in the soil of nineteenth century stereotypes about women, particularly about the "derangement" of intellectual women.

The "ideal" woman was intended to be an adornment for the thirty or more pounds of clothes she wore when she was fully dressed in waist pinchers which caused fainting spells and bustles which caused kidney problems. Enforced idleness was the suffocating condition of the middle-class woman. It led to chronic invalidism, headaches, and physical weakness, conditions considered chief elements in the estheticism of femininity. In her book Cassandra, Florence Nightingale cried out against the crippling idleness which dragged women into unreality and fantasy lives, not infrequently to madness, the famous female "hysteria" of the nineteenth century, the prescribed cure for which was often clitoridectomy and hysterectomy.

Elizabeth Blackwell accused the medical profession of having castrated 500,000 women in Europe and was drawn to medicine because she saw it as a women's issue. She understood that many so-called "female diseases" had their roots in the crippling apparel and lives women led and in the pathological relationship that had developed between women and the medical profession in the nineteenth century.

The century began with the woman as symbol of innocence and purity, a nineteenth century re-invention of the Roman household goddess and vestal virgin. Medicine became fascinated with woman's reproductive system during the century, and scientists lectured them on their biological destiny, which included the judgment that learning diminished a woman's capacity to bear children. Nineteenth century science was obsessed with gender and race, legacies bequeathed to the social domains of our century. Scientists located woman, according to the evolutionary doctrine of the day, along the level of the dark races, both being seen as infantile, animal-like, and belonging to nature, while the white male belonged to civilization. "Nature," however, was not regarded as a benign force but as the omnipresent atavistic possibility to be resisted.

It was a short step to the identification of women with animals, and as Cynthia Eagle Russet observes, "Kinship with animals raised disturbing reflections, not least the possibility that civilization was not more than a thin veneer over the savage self."5 The century ended with a significant reversal of view about woman, now fearing her as a femme fatale, a being possessed of dark 
animal powers. Throughout much of the century, as Russet observes, there was "a geography of scientific misogyny, with the most overt and brutal antifeminism being voiced on the European continent. ${ }^{6}$

The pronounced presence of women in the antivivisection movement augmented suspicion about their allegiance to the human race and gave rise to the notion that to protest animal cruelty is to be "anti-human." Frances Cobbe, who had spent her life in social causes and had worked several years in the slums of Bristol responded to this charge with restrained glee.

\begin{abstract}
Readers who have reached this twentieth chapter of my Life will smile,... at the ascription to me in sundry not very friendly publications, of exclusive sympathy for animals and total indifference to human interests. I have seen myself frequently described as a woman "who would sacrifice any number of men, women, and children, sooner than that a few rabbits should be inconvenienced.' Many good people apparently suppose me to represent a personal survival of Totemism in England; and to worship dogs and cats, while ready to consign the human race generally to destruction.... the years which I spent ... working in the slums of Bristol, ought, I think, to suffice to dissipate this fancy picture.
\end{abstract}

This extraordinary woman-of whom E. Westacott has written with disarming simplicity: "An Irish lady, Frances Power Cobbe, must forever be associated in England with the beginning of an organized movement against the cruelties of science," 8 - was bom in 1822 , a fact which gave her much pleasure, for it was in that year that the first piece of legislation against animal cruelty was passed in Parliament. This was "Martin's Act," initiated by a fellow Irishman. She was also proud of her middle name and believed that her power had been inspired by an inscription on her great-grandfather's chair: "Deliver those who are oppressed from the hand of the adversary." It was a chair she came to occupy very well, being responsible for legislation affecting women's rights to own property and to sue for divorce on the grounds of physical abuse and for establishing anti-vivisection as an international crusade.

Cobbe was not beautiful, being corpulent, like Gertrude Stein. As a journalist for such well-known English publications as Fraser's and Cornhill, she came to know almost everyone in the English literary and intellectual world: Charles Darwin, the Brownings, Carlyle, Cardinal Manning, and the Seventh Earl of of Shaftesbury, who became her most important aid in establishing the English Anti-vivisection Society. She could boast with justice that she was pre-eminently in a position to speak for the female intelligence since, excepting George Eliot and Harriet Martineau, she had known every prominent female writer and artist of her era. And indeed she had!

Her intellectual appetite was formidable and versatile. By the time she was sixteen, she was reading Edmund Spenser, Milton, Dante, Homer, the Greek dramatists and historians, and Gibbon. At eighteen she underwent a religious crisis and became a Theist. The first heretic in a family which boasted of five archbishops, she was banished to Donegal by her father, awaiting her repentance. He was something of a tyrant, she admitted, on the model of the Roman patriarch. Her mother is characterized as a gentle, liberal woman, a close companion to Cobbe, whose childhood on their secluded manor outside of Dublin, with four older, distant brothers, was a lonely one. Recognizing a kindred obstinate spirit in his daughter, her father recalled her from Donegal, whereupon she wrote a spiritual treatise, Broken Lights, and a critique of Kant, Essay on the Theory of Intuitive Morals, (1855). Her record of the birth of this work reveals the hilarious and macabre nineteenth century concerns about female intellectuality.

I had all along told my father ... that I was going to publish a book; of course, anonymously, to save him annoyance. When the printing was completed, the torn and defaced sheets of the MS. lay together in a heap for removal by the housemaid. Pointing to this, my poor father said solemnly to me: 'Don't leave those about; you don't know into whose hands they may fall.' It was needless to observe to him that I was on the point of publishing the 'perilous stuff!'

The reviews amused her even more, all in the vein of The Caledonian Mercury "It is a most noble performance, the work of a masculine and lofty mind." When, however, the rumor of female authorship was confirmed, the reviews changed to: "Our dislike is increased when we are told it is a female (!) who has 
propounded so unfeminine and stoical a theory.... and has contradicted openly the true sayings of the living God!" (Christian Observer). Her comment regarding female disabilities in her youth was, "The laws which concerned women at that date were so frightfully unjust that the most kindly disposed men inevitably took their cue from them, and looked on their mothers, wives, and sisters as beings with wholly inferior rights; with no rights, indeed."

Passionately, Cobbe urged women to fight for their rights:

Take the sorrows, the wants, the dangers (above all the dangers) of our sisters closely to heart, and, without ceasing to interest yourself in charities having men and boys for their objects, recognize that your earlier career should be for the weakest, the poorest, those whose dangers are worst of all.... think of all the weak, the helpless, the wronged women and little children, and the harmless brutes; and save them and shield them as best you can; even as the mother-bird will shelter and fight for her little helpless fledgelings. This is the natural field of feminine courage. ${ }^{9}$

Cobbe's early career as a journalist was devoted to exposing brutality toward women, described in such language as "not merely struck, but maimed, blinded, burned, trampled on by strong men in heavy shoes and in many cases murdered outright." Sights she was to witness in her anti-vivisection work forced her to see a parallel between the conditions of women and animals, and she entitled two sequential chapters in her autobiography, "The Claims of Women" and "The Claims of Brutes."

Throughout the nineteenth century there were porous boundaries between the various reform causes, and those involved in anti-slavery, prison reform, and child abuse reform were often the same people involved in the women's movement, anti-vivisection, slum clearance, and the hygiene or sanitary movement, which gave rise to our modern concept of public health. Elizabeth Blackwell was a friend of Harriet Beecher Stowe, and two of her brothers, staunch abolitionists (as was the whole family), married suffragettes. One of these was Lucy Stone, who was also an abolitionist, and the other was Antoinette Brown, the first American woman minister. Frances Power Cobbe was instru- mental in getting the first women's property law passed, which made it possible for married women to own property, and in getting legislation passed which permitted a woman to divorce her husband for beating her. Upon hearing that a woman had said that the legislation which allowed her to divorce her husband had given her back her life and made it possible for her to live, Cobbe remarked, "May I not close my eyes on this world without doing as much for the animals."

Cobbe put her faith in legislation, believing that the importance of the vote was that it allowed human beings to transform vision into law. The vote was not a right but a duty toward the betterment of the world. With others in the coalition of nineteenth century reform movements, she located evil not in a mysterious ontology but in institutions that could and must be reformed, for as she observed: "In almost every case it is only by legislation that the roots of great evils can be reached at all, and that the social diseases of pauperism, vice, and crime can be brought within the hope of cure."

With this optimism she set about, in 1875 , to introduce a bill which would reform vivisection. Her persistent belief was that evil was a human activity, and vivisection, with its insatiable cruelty, was not a gift from God for the healing of human beings but the result of a demented philosophy characterized by what she called the "dilettantism of discovery."

For several decades rumors had come from continental Europe to England concerning horrendous experiments being performed on living animals, often unanesthetized. During a visit to Florence, Italy, where Cobbe had a villa at Bellosquardo, she became involved with drafting the first anti-vivisection petition, after hearing of grotesqueries at a laboratory at the Speculo, substantiated by reputable eyewitness accounts. But the experimenter denied the accusations or claimed that the animals had been anesthetized. Then, several years later, in The Morning Post for February 2, 1875. was a letter by Dr. George Hoggan, a former assistant to Claude Bernard, who came out of the closet-or more pertinently out of the laboratory. His lengthy letter described the hell that Anna Kingsford was later to find in France:

I have often heard the professor say, when one side of an animal had been so mangled, and the tissues so obscured by clotted blood, that it was difficult to find the part searched for, 
"Why don't you begin on the other side?" or, "Why don't you take another dog? What is the use of being so economical?" One of the most revolting features in the laboratory was the custom of giving an animal, on which the professor had completed his experiment and which still had some life left, to the assistants to practise the finding of arteries, nerves, etc, in the living animal. ${ }^{10}$

His letter pointed out the hypocrisy of anesthesia which, he claimed, was "far more efficacious in lulling public feeling toward the vivisectors than pain in the vivisected."11

Cobbe immediately contacted Dr. Hoggan. Together, with Dr. Hoggan's wife, they formed the Victoria Street Society in March, 1876, known formally as the First Society for the Protection of Animals Liable to Vivisection. Cobbe was its head for eighteen years, during which time she published The Zoophilist, an antivivisection journal, and wrote The Modern Rack. The First Royal Commission into Vivisection was formed in June, 1875. Cobbe introduced legislation to the commission and was indefatigable in collecting signatures on petitions to Parliament, including 2,000 clergy from the Church of England and 2,000 members of the Society of Friends. The Commission sat for one year and interrogated 53 witnesses. Many who gave testimony on behalf of the animals were eloquent, learned, and utterly persuaded that humankind had a duty to itself as well as to animal life to destroy the vivisection movement. From its initial appearance as an academic discipline, vivisection had been beset by an inherent contradiction: it is an evil which cannot be halted and for which, therefore, reform is the only possible recourse; however, as Anna Kingsford protested, to argue for the "reform" of vivisection is like arguing for the "reform" of murder; to concede the principle is to concede the argument.

Frances Power Cobbe's faith in legislation and the reform process was shattered when her bill went down to defeat, replaced by another which allowed greater latitude for the researcher. "The world has never seemed to me quite the same since that dreadful moment," she wrote. "I was baffled in an aim nearer to my heart than any other had even been, and for which I had strained every nerve for months.... Justice and mercy seemed to have gone from the earth." She became thereafter an abolitionist, forming the British Union for the Abolition of Vivisection, viewing vivisection as the crucible question for the coming century.

There is a prophetic peroration in her final estimate of the problem:

We stand face to face with a new vice, new, at least in its vast modern development and the passion wherewith it is pursued-the vice of scientific cruelty. It is not the old vice of cruelty for cruelty's sake. It is not the careless brutal cruelty of the half-savage drunken drover, the low ruffian who skins living cats for gain, or of the classic Roman or modern Spaniard watching the sports of the arena with fierce delight in the sight of blood and death. The new vice is nothing of this kind.... Sometimes it would appear as we read of these horrorsthe baking alive of dogs, the slow dissecting of quivering nerves - that it would be a relief to picture the doer of such deeds as some unhappy, half-witted wretch.... But, alas! this new vice has no such palliations; and is exhibited not by such unhappy outcasts, but by some of the very foremost men of our time ... men addicted to high speculation on all the mysteries of the universe; men who hope to found the Religion of the Future....

The characters of the Nazi doctors, erudite and barbarous, would not have surprised her.

Bitter and disappointed at the end, she labored in a practical way better than she knew, for the legislation which was passed at least constrained vivisection in Great Britain to research purposes and restricted its use for purposes of education or demonstration. Millions of animals, at least in England, have been saved from student vivisection. Furthermore, the seeds of her work took root all over the Western world, in Italy, France, Belgium, from Scotland to the United States, with branch memberships numbering in the tens of thousands and world membership in the millions. In Sweden the establishment of an Anti-vivisection League drew the attention of two lively young ladies, Liesa Katarina Schartau and Emilie Augusta Louise Lind-af-Hageby. Emilie was the more forward of the two, lecturing and writing in the Swedish press on social issues which included the women's movement, the problem of legalized prostitution, housing, and prison reform. As E. Westacott observes of her, "Her championship and 
that of Miss Schartau of the cause of the animals was ... the culmination or blessing of a general humanitarian outlook."12

Both had been born to comfortable, privileged classes during the 1870's. They had been well-educated and were enthusiastic about the new scientific discoveries of the era. In 1900, they traveled through Europe and stopped at the Pasteur Institute in France, the jewel in the crown of science at the time. In an address delivered in Geneva in 1926, Lind-af-Hageby recounted the experience:

My Anti-vivisection life was born in the Pasteur Institute in Paris in the year 1900. Together with my friend and colleague Miss Liesa Schartau I had decided to pay a visit to this famous centre of medical research. We went to learn and admire. The sights that confronted us were startling. We found cages upon cages, vast rooms filled with hundreds of animals that had been inoculated with diseases. They were suffering and dying. The dead lay in some cases with the living. Now and then the young and amiable man who conducted us through the Institute opened the door of a cage, took out the dead body of a rabbit or a guinea-pig, and threw it into a pail under the table.... from that moment the fate of vivisected animals became my constant concern. ${ }^{13}$

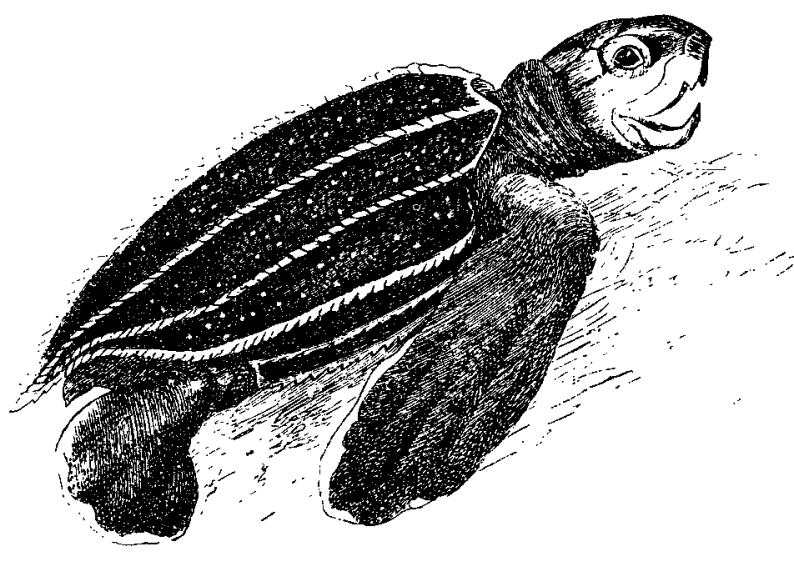

Determined that their opposition to vivisection would be respected as medically expert, they entered the Women's School of Medicine in London in 1902 for degrees and subsequently wrote a book called EyeWitnesses: Extracts from The Diary of Two Students of Physiology, later called The Shambles of Science. The book went through five editions by 1913 and ignited protests that shook England for years. It became to the anti-vivisection movement what Uncle Tom's Cabin was to the anti-slavery movement. The focus of agitation was a chapter called "The Vivisection of the Brown Dog," which gave an account of two experiments by two professors on the same dog, inadequately anesthetized or not anesthetized at all, in violation of regulations in the 1876 legislation that the same animal may not be used for a sequence of vivisections. The accusation led to a libel suit by Dr. Bayliss, one of the vivisectors. The suit was dismissed for lack of sufficient evidence, but Dr. Bayliss was awarded $£ 2,000$ for damages. A subscription fund of $£ 5,735$ was raised for the defendants and presented to Lind-af-Hageby and Liesa Schartau with a list of signatures, beginning with the name of Frances Power Cobbe.

The historical moment was apt, for the torch was passed to two women very capable of following in Cobbe's footsteps. They founded the provocative and influential Animal Defense and Anti-Vivisection Society, which opened shops in Sloane Street and Piccadilly to distribute anti-vivisection material to the public and the press. The story of the Brown Dog went on to have a startling career. Anna Louise Woodward, the founder of the World League Against Vivisection, raised a public subscription to pay for a bronze statue to commemorate the fate of the brown dog. The statue was erected in Battersea Park across the road from University College. It was unveiled by the Mayor of Battersea on September 15, 1906 and bore this inscription:

In Memory of the Brown Terrier Dog done to death in the Laboratories of University College in February

1903, after having endured Vivisection extending over more than Two Months and having been handed from one Vivisector to another till Death came to his Release. Men and women of England, How long shall such things be? 
It remained undisturbed for a year, until November 20,1907 , when a group of medical students decided that their reputation was being maligned and attempted to destroy the statue. Defenders immediately appeared, and for a year and a half Battersea Park was the scene of almost nightly riots between anti-vivisectionists and medical students. The statue disappeared in early February, 1908, to the relief of the police, who had complained that they could no longer afford to keep the peace. A protest demonstration, attended by thousands, was held in Trafalgar Square in March, at which Lindaf-Hageby repeated the story of the Brown Dog.

The incident has inspired two books, one by Edward Ford in 1908 and more recently, The Old Brown Dog: Women, Workers, and Vivisection in Edwardian England, by Dr. Coral Lansbury. The title is an indication of the coalition among classes that the anti-vivisection cause inspired a century ago. The statue of the Brown Dog has become an enduring symbol of vivisection cruelty, and the struggle against it, for it has been rebuilt and put back in Battersea Park, where it once stood, erected and protected with great passion.

The press took note of the riots and the trial which had preceded them, and almost all supported the antivivisectionists. As John Vyvyan notes, we can measure the moral tide by the fact that few newspapers today would consider the fate of a dog a newsworthy item or "would now champion a dog against a professor, or uphold the claims of mercy against those of science." 14

The Shambles of Science was a source of evidence during the Second Royal Commission into Vivisection, begun in 1906, and Lind-af-Hageby was called to give testimony on four occasions, demonstrating such skill and knowledge in handling the medical technicalities involved in the experiments she evaluated that one medical witness from the opposition stated that he regretted that the two girls had been admitted to medical school.

Outside the rigorous demands of giving such testimony, Emily Augusta Lind-af-Hageby was flamboyant and memorable. As Vyvyan describes her, "She was one of the diminished band of speakers whom no hooligans could silence.... In those days, she was very good-looking; and when the young demonstrators were not releasing stink-bombs or shaking rattles, they were blowing her kisses. For those with stamina, the proceedings could be fun; but her response to the kisses was blistering scorn. She was a natural orator, dauntless under attack."
Out of the Brown Dog agitation she helped created an organization allied to the Anti-Vivisecrion Council, The International Medical Association founded in 1905, with a membership of hundreds of medical men and women, "to encourage biological research unconnected with vivisection and all 'scientific pursuits ... free from the taint ... of a painful and violating kind." "15

In opposition to the gathering strength of the antivivisection organizations, Stephen Paget founded the Research Defense Society in 1908 and opened up a shop in Picadilly next to that of the Animal Defense and AntiVivisection Society. The credo of anti-vivisectionists, which Lind-af-Hageby wrote in 1908, took note of the challenge of the Research Defense Society in language that reminds one of Antigone explaining her position to Creon, in its appeal to a gnosis beyond that of state and institution:

The formation of the 'Research Defense Society' and the promulgation of its guiding principle ... viz., that 'the small amount of pain or discomfort inflicted is insignificant compared with the great gain to knowledge and the direct advantage to humanity' ... cannot ... stay or undermine the AntiVivisection Movement. Our cause is above the objects and principles of the new Society. Our Cause is based on the claims of morality, on the supreme and ancient faith in a spiritual law which is above science, health and sickness, even-though the Vivisector know it notabove life and death.

In a lifetime of combatting scientific cruelty and in faith to her spiritual law, she and Liesa Schartau exposed vivisection practices in one institution after another, in the United States and in Europe, and left a legacy of data for anti-vivisectionists with which to confront the prevailing secrecy of vivisection practices.

Among other remarkable female personalities in the anti-vivisection movement at this time, Anna Kingsford was the most memorable to her generation, not only for her combination of beauty and intellect, but also because there was a somber mysticism to her character. She was compounded of rapture and shadow, of light and darkness. She believed that she possessed psychic powers, and among those who were inclined to agree with her was one of her instructors, Charles Richet, a renowned vivisector. Her thesis for her medical degree 
at the Collège de Médecine in France was on vegetarianism as the perfect, healthy diet for human beings. It also included a moral evaluation of vegetarianism, which Charles Richet, with others on her examining board, demanded she delete. They concurred that her "scientific" evaluation of nutrition and human health was satisfactory, but moral statements had to be excised.

Kingsford reinstituted the deleted passages after her graduation and published the thesis with her companion, Edward Maitland, under the title, The Perfect Way In Diet. The book gave rise to several vegetarian societies and influenced nineteenth century vegetarian thought. Even her opponents were fascinated by her, and Charles Richet hosted a vegetarian dinner in honor of her degree.

In spite of bad health Kingsford had a will of iron and a rebellious streak which confounded her instructors. She was determined never to engage in vivisection and to force them to give her a medical degree on her own terms, not only because she loathed the practice but also because she wished to prove that one could become a competent doctor without recourse to instruction in vivisection. She was passed from instructor to instructor, as each failed to dissuade her from her views, and her six years at the College de Médecine were a constant battle. But she was the first Englishwoman to gain a medical degree from the Faculté de Médecine, and she graduated second in her class - and she did it her way. But of her stay in Paris, and in the College, so close to the vivisection laboratories that she frequently heard the animals groaning, she wrote: "I have found my hell here."

She was born in 1846 in Stratford, Essex, to a wellto-do merchant family. The youngest of twelve children, at an early age she displayed heightened intellectual and psychological qualities. She was writing poetry at the age of nine and getting it published. But she was also sickly and suffered all her life from asthma, neuralgic pains, headaches, and lung problems, which finally ended her life at the age of forty-two. In spite of bad health, after gaining her medical degree she maintained a strenuous lecturing schedule throughout the British Isles, France, Italy, and Switzerland. She helped establish anti-vivisection societies in Geneva, Paris, Lausanne, and Berne.

She had married a cousin on New Year's Eve, 1867, and was blessed with an understanding and liberal husband who recognized that her unusual qualities demanded an unusual life. They began their marriage with the agreement that she would be free to follow her talents and destiny. He became an Anglican clergyman, while she became involved with the feminist movement and published The Ladies Own Paper. When she discovered vivisection, it represented for her the quintessence of evil, and she devoted the rest of her life to combatting it. Like Liesa Schartau and Lind-afHageby, she recognized that a medical degree would confer credibility on her protest. But since there were no medical schools in England that a woman could go to at this time (she preceded Schartau and Lind-afHageby by a few decades), she went to Paris. Because her health was poor, her husband agreed that a friend, Edward Maitland, would accompany her. He became, in due time, something between an intellectual and spiritual companion, nurse, confidant, protector, and perhaps lover. The rest of her life and writing is inseparable from his. She was twenty-seven when they met; he was forty-nine and a writer of note himself. Theirs became a deeply collaborative life. Though the arrangement may have been platonic, it was not conventional. Anna Kingsford found herself barred from membership in Cobbe's organization, as well as other organizations, but in Maitland she found an indispensable support for her feminist and anti-vivisection work. He was a forerunner of those who believe that humankind can only be saved by releasing the feminine energies in man.

She was driven by a spiritual hunger, which led her first to convert to Roman Catholicism and then, disappointed by official Catholic teaching on animals and by its formal dogmatic structure, to turn to Theosophy, where she had her greatest impact: Theosophical thought was hereafter identified with vegetarianism and an anti-vivisection position. Both Maitland and Kingsford belonged to a world unknown to Cobbe, and they influenced a public her movement overlooked, the Theosophical and Fabian societies.

Anna Kingsford became legendary in her day. When she died in February, 1888, obituaries appeared as far away as Germany. One admirer wrote:

Truly she was a peerless and a matchless woman.... the greatest opponent of vivisection, and the most powerful writer against it, of any in England.

Vyvyan recounts that "Edward Berdoe, a Member of the Royal College of Surgeons, described her as the 
most learned, the most beautiful, and the most spiritually-minded woman he had ever met." 16

Kingsford also was a great orator, and her command of language, whether in writing or speaking, invariably affected those who heard her lecture and who read her articles. She described the poor sick as "the pauper victims of experimental medicine" and noted, as Elizabeth Blackwell did, the contempt with which they were treated. Her writing about her work, like her writing on animal research, resonates with horror at human cruelty. Yet a few days before she died, Kingsford wrote the following:

This is now the eleventh month of my illness. And all the while my spirit is alive and beating its wings like a caged wild-bird against the bars of this body of death, longing to be away, out yonder in the clear high blue of the supernal height.... O sweet, sharp wind blowing between the turfy spaces of the hills, laden with bean and clover scents, I feel you on my face! I greet you. You are full of health and comfort. Deep, deep dome of the holy sky, up there above the fir-trees, I look towards you reverently. ${ }^{17}$

Presciently, Kingsford had written earlier that, "The great need of the popular form of the Christian religion is precisely a belief in the solidarity of all living things." No stranger convert to Catholicism can have existed. She became the gadfly of the Pope and the Catholic clergy; she dismissed the doctrines of resurrection, heaven and hell, confession, and vicarious atonement, believing that one can suffer for another and with another but not instead of another. But the doctrine of transubstantiation corroborated her belief in religious alchemy, in the transformation of earthly phenomena into spirit. She cared nothing about the historical church or its historical personages. The history of the soul, worked out in a theory of reincarnation, was the central point of her religious life. The mission of Theosophy, for her, was to unite science and religion, heart and mind, love and learning, nature, thought and intuition, the noumenal and the phenomenal. In her work, Clothed with the Sun, she expressed her belief that "All matter is impregnated with spirit," and that the problem of health and disease had to address itself to the unity of body and soul.

This insight and the great moral question of whether the end justifies the means animate the debate of anti-vivisectionists. Religion and morality are the cornerstones of their argument. Elizabeth Blackwell wrote:

Methods run with the manners and customs of the ages. In Science there is no one method that can be considered indispensable. Attributes are indispensable; observation, industry, accuracy are indispensable; methods are not. They may be convenient, they may be useful; they may be expedient, but nothing more.

And elsewhere: "What we can do, is not a measure of what we ought to do."

Born in 1821 in England, one of twelve children in a Dissenter family which came to the United States when she was eleven, Blackwell was raised mainly in Cincinnati and was the first woman in modern times to graduate with a degree in medicine. She attended Geneva Medical School in upstate New York, where she was frequently taunted by children in the street as a freak of nature. As a practising physician, she was among the first to accept Semmelweis' teaching that doctors themselves were spreading puerperal fever, and in a long life of delivering babies she lost only one woman to this disease. She shared with her friend Florence Nightingale a passionate commitment to health as hygeia, to prevention rather than cure, to clean air, clean sheets, clean rooms and clean water, and to sanitation and hygiene. In 1871 she formed the National Health Society in England, stressing preventive medicine, sanitation, and public health. In 1866 she initiated a program of visiting homes to instruct poor women in hygiene, which became the "forerunner of the vast network of district nurses, social workers, public health workers, and a host of other such functionaries." ${ }^{18}$ She trained Rebecca Cole, the first Black female doctor, in this work.

In 1868 Blackwell established The Women's Medical College and New York Infirmary. It was the first medical college to establish a chair of hygiene, and it gave instruction in the "sanitary investigation of air, water, and soil; ventilation and heating; the study of food and clothing; sterilization and disinfectant; disposal of sewage; climatology, sanitary relation of habitations to soil drainage; and general household hygiene."19 If all this sounds modern, it came from a woman who regarded medicine as "spiritual maternalism," who believed that genuine science was rooted in conscience, in distinction 
to what she called "unguided intellectual activity or curiosity." Almost her first act as a doctor was to establish a free dispensary in New York slums.

Blackwell wrote a book on the sexual education of children, which she was forced to publish herself, and other books on such subjects as How to Keep a Household in Health; The Religion of Health; Medicine and Morality; The Human Element in Sex; and Scientific Method in Biology. This last book deplored animal research and its effects on students: "The student becomes familiar with the use of gags, straps, screws, and all the paraphernalia of ingenious instruments intended for overpowering the resistance of the living creature.... He learns also how easy it is to experiment in secret." 20

In 1859 Blackwell was the first woman doctor to be entered in the British Medical Registry. During the Civil War her dispensary was almost burned down twice, and she herself escaped a pro-slavery lynching mob by the good fortune of someone recognizing her as the woman who was a doctor for the poor. In 1875 she was given the chair of gynecology in the New Hospital and London School of Medicine for Women.

Blackwell did not take an active role in the antivivisection crusade, but her entire career as a doctor contrasted with the growing industry of animal research, and she wrote in her multi-volume work, Medicine and Society in America: Essays in Medical Sociology, that "The subject of experimentation upon the lower animals, having two aspects-an ethical and an intellectual one.... It must be recognized that the people are absolutely in their right in refusing to submit to dictation in what concerns their relation to animal life, of which they are the responsible head." ${ }^{21}$ She counted among her friends and supporters Horace Greeley, founder of The New York Tribune, Henry Raymond, founder of The New York Times, the abolitionist William Lloyd Garrison, William Henry Channing, Florence Nightingale, and Charles Kingsley.

These are the women, among others, who were called "anti-human," "anti-intellectual," "obscurantists," and sentimentalists," as anti-vivisectionists are still labelled. The language of the animal research community, formulated in nineteenth century misogyny, continues this diatribe.

Descartes' determination to render life measurable, quantifiable, and without intimations of vitalism or soul gave science its epistemological foundation, but it created what Theodore Roszak has called "Cartesian apartheid," 22 where "styles of knowing" are estranged from each other. Knowledge is opposed to wisdom; truth becomes only scientific truth; progress becomes only scientific progress; reason is opposed to sentiment; and science is opposed to morality and becomes indifferent to moral arguments. A methodology, an intellectual tool claimed to be the established order of things, becomes the only way of knowing. As Jacques Maritain observed, "Henceforth, between reason and mystery, between science and faith, the antinomy is inevitable." ${ }^{23}$ And henceforth, in the nomenclature of the nineteenth century, all who oppose animal research are regarded as backward, irrational, sentimental - in a word, "womanly." The intellectual edifice identifies itself as masculine, science as masculine, logic and rationalism as masculine activities, and the medical profession casts vivisection as the apex of the scientific esprit de corps.

When Anna Kingsford presented herself at the College de Médecine as an applicant for the medical degree, one professor remarked that he supposed that now a woman was going to medical school, "we would have to allow sentiment." Her response, given later in an article, was "They speak sneeringly of 'sentiment.' The outcry against vivisection is mere 'sentiment.' Why, in God's name, what is so great, so noble as human sentiment! What is religion, what is morality, but sentiment?"

Little has changed in the criticism by the animal research community. Though so radical a doctrine as the beast-machine could not be advanced without calling into question cardinal religious principles, such as the nature of God, of creation, of the soul, and of teleology, physiologists drew then, and still do, their arsenal of contempt for anti-vivisectionists from the woman's movement which, in the nineteenth century, crossed the path of the anti-vivisection movement with historic force.

\section{Notes}

${ }^{1}$ Leonora Cohen Rosenfield, From Beast-machine to Manmachine: Animal Soul in French Letters from Descartes to La Mettrie (Oxford University Press, 1941), p. 163.

${ }^{2}$ Ibid., pp. 112-113.

${ }^{3}$ E. Westacott, A Century of Vivisection and AntiVivisection (C. W. Daniel Company Ltd., 1949), p. 24. 
${ }^{4}$ lbid, pp. $170-171$.

${ }^{5}$ Cynthia Eagle Russet, Sexual Science: The Victorian Construction of Womanhood (Harvard University Press, 1989), p. 297.

${ }^{6}$ lbid., p. 190.

${ }^{7}$ The Life of Frances Power Cobbe By Herself (Houghton Mifflin, 1894), p. 556.

${ }^{8}$ E. Westacott, p. 24.

${ }^{9}$ The Life of Frances Power Cobbe By Herself, p. 554.

${ }^{10}$ John Vyvyan, In Pity and In Anger (Micah Publications, 1988), p. 77.

${ }^{11}$ E. Westacott, p. 31.

${ }^{12}$ Ibid., p. 189.

13 John Vyvyan, The Dark Face of Science (Micah Publications, 1989), pp. 31-32.

${ }^{14}$ Ibid., pp. 57-58.

${ }^{15}$ E. Westacott, p. 195.

${ }^{16}$ In Pity and In Anger, p. 138.

${ }^{17}$ Ibid, p. 153.

${ }^{18}$ Dorothy Clarke Wilson, Lone Woman: The Biography of Elizabeth Blackwell (Little Brown \& Co., 1970), p. 405.

${ }^{19}$ Ibid., pp. 415-416.

${ }^{20}$ Elizabeth Blackwell, Medicine and Society in America: Essays in Medical Sociology (Arno Press, 1972), p. 112.

${ }^{21}$ Ibid., p. 103.

${ }^{22}$ Theodore Roszak, "The Monster and the Titan: Science, Knowledge, and Gnosis," Science and Its Public: The Changing Relationship, Daedalus (Summer, 1974), p. 22.

${ }^{23}$ Jacques Maritain, The Dream of Descartes, tr. Mabelle L. Andison (Kennikat Press, 1944), p. 80.

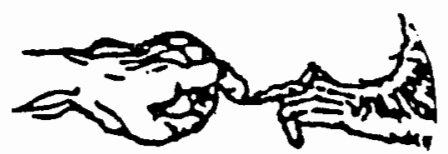

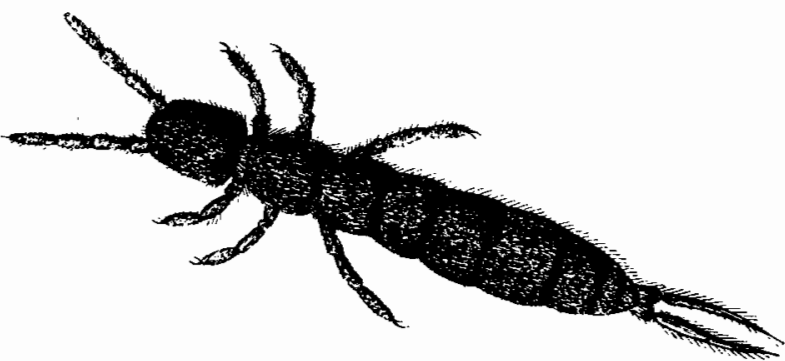

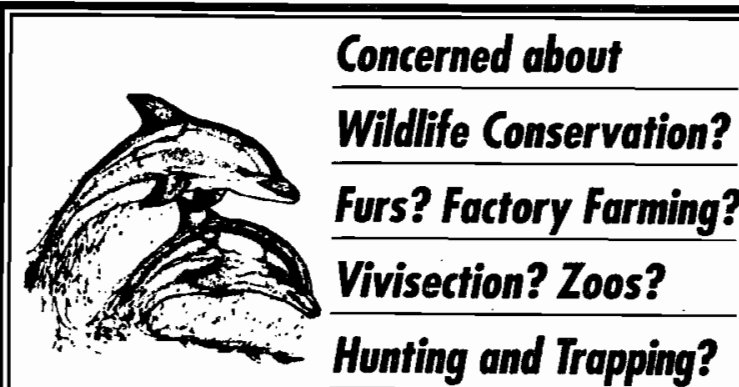

WE ARE TOO....

Did you know that philosophers have also made a contribution to the growth of the animal liberation movement? - Think of Regan, Singer, Clark, Magel, Rollin and Sapontzis.

Berween the Species "is the only publication which allows such extensive examination of the philosophical basis for animal rights." - Brad Miller, Humane Farming Association

Subscribe foday - and please send your tax deductible contribution -help us guarantee philosophers a forum in which to continue to evolve a sound basis for animal rights.

$\$ 16.00$ from

San Francisco Bay Institute

P.0. Box 254

Berkeley, CA 94701

Sample back issue $\$ 3.00$

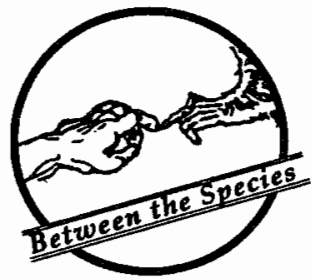

Quarterly Journal of Ethics

\section{PHILOSOPHICAL ACTIVISM NEEDS YOUR SUPPORT!}

